\title{
Developing Marketing Strategies for Green Grocers: An Application of SERVQUAL
}

\author{
David B. Eastwood \\ Department of Agricultural Economics, University of Tennessee, \\ 2621 Morgan Circle, Knoxville, TN 37996-4518. E-mail: eastwood@utk.edu \\ John R. Brooker \\ Department of Agricultural Economics, University of Tennessee, \\ 2621 Morgan Circle, Knoxville, TN 37996-4518. \\ James D. Smith \\ Department of Agricultural Economics, University of Tennessee, \\ 2621 Morgan Circle, Knoxville, TN 37996-4518.
}

\begin{abstract}
Successful food retailing depends to a significant degree on providing a positive shopping environment for consumers. The SERVQUAL format is one way of gathering information about shoppers' ideal and actual ratings of an outlet's characteristics. Three modifications of the conventional application of the questionnaire are described. Implementation of the methodology is shown to be an effective tool for a retailer to identify strengths and weaknesses with respect to patrons' evaluations of outlet characteristics. Six green grocers were selected to reflect the diversity of outlets in a state, and the survey was conducted in the spring of 2000. Results indicate consumer ratings vary by feature group for ideal, actual, and actual minus ideal subgroup scores. The information can be used to generate better store-specific strategies to meet consumer expectations. [EconLit citations: C42, Q13.] (C) 2005 Wiley Periodicals, Inc.
\end{abstract}

\section{INTRODUCTION}

Consumer awareness of the benefits of fresh produce consumption is increasing as national programs (e.g., 5-A-Day and the Food Pyramid) and media coverage of the results of new health studies reach more people. Such information is consistent with the rise in per capita consumption of fresh produce. At the same time, changes in production and distribution of fresh produce have enabled year-round availability of many commodities. However, changes in the commercial produce distribution system have made it difficult for many consumers to find locally grown fresh produce in season at large retail outlets, such as supermarkets and supercenters. A large part of the problem is due to smaller volume produce operations having difficulty gaining access to the commercial distribution system (e.g., Calvin et al., 2001), although there are instances of large chains of food retailers that do have procurement of local supplies when available. Smaller growers have trouble covering costs associated with providing marketing services and incentives required 
by large-volume retailers (Dimitri, Tegene, \& Kaufman, 2003). These growers have pursued some alternative venues including co-operatives, farmers' markets, and direct outlets (e.g., Govindasamy et al., 1998; Lawless et al., 1996; Rhodus, Schwartz, \& Hoskins, 1994).

Little consideration has been given in the literature to green grocers. These are retail stores whose principal sources of sales are fresh produce. They have heated buildings that are open year round and have parking available for customers. Although neglected, these outlets possess several advantages for people who want locally grown fresh produce. ${ }^{1}$ Green grocers tend to be spread throughout metropolitan areas, as opposed to direct outlets, such as farmers's markets and on-farm locations, so travel costs for customers more closely approximate those of grocery stores. Many consumers like the personal attention, quality, and freshness afforded by green grocers, as well as the convenience of not having to search for items they want to buy in large stores. Advantages to growers from selling to green grocers include avoidance of the need to rent spaces at farmers' markets and having their own sales people at stands. Smaller production volumes are also more compatible with the sales volumes of green grocers.

These considerations suggest there is a good match between the supply and demand needs of green grocers and small volume growers. Market opportunities for the latter can occur as green grocers respond to increased consumer demand. A critical component of increasing sales is the provision of positive shopping experiences for customers. Therefore, an assessment of shoppers' perceptions of outlet features can be a key component of increased demand. This paper presents an analysis of shoppers' perceptions of green grocers with respect to ideal and actual store features.

\section{THE SERVQUAL QUESTIONNAIRE}

Customer satisfaction depends, in part, on store features, experiences with employees, and the checkout process (Dabholkar, Thorpe, \& Rentz, 1996; Parasuraman et al., 1988; Zeithaml et al., 1990). Initial research measuring service quality led to the creation of the SERVQUAL format. The objective has been to obtain an overall measure of quality, or excellence, based on customer expectations versus experience (Bearden \& Netemeyer, 1999). The surveys typically consist of paired responses to statements about store attributes and customer satisfaction. One set is to reflect a respondent's ideal ratings features, and the other is based on the person's experience (often the most recent). Likert scales are used to record the information. The measurements are then transformed into overall ratings of service quality (Colley, 1996).

Results have been used as measures of performance and incentive programs for airlines, banks, nurseries, and parcel delivery (e.g., Anderson, Fornell, \& Lehman, 1994; Behe \& Barton, 2000; Bitner, 1990; Bouman \& van der Wiele, 1992; Colley, 1996; Fick \& Ritchie, 1991; Hudson et al., 1998; Lovelock, 1992; McDaniel \& Lourgand, 1994; Mersha \& Adlakha, 1992; Rigotti \& Pitt, 1992; Stevens, Knutson, \& Patton, 1995; Young, Cunningham, \& Lee, 1994). The difference between the ideal and actual ratings have been used as measures of the gap, or disconfirmation between expectations and experiences (e.g., Oliver, 1997; Spreng, MacKenzie, \& Olshavsky, 1996).

\footnotetext{
${ }^{1}$ No national data are available on the number of green grocers, or their sales. A 1999 survey for Tennessee using information gathered from County Extension Agents, the Yellow Pages for the largest metropolitan areas, and a computerized directory of businesses by SIC code resulted in the identification of 154 green grocers operating in the state.
} 
Research has focused on the creation of statements that could be combined to create consistent indices of service quality. The set of statements varies by type of product or service under study. Correlations and factor analysis have been used to test the reliability of the statements and their relevance for generating overall scores for specific goods and services (Parasuraman, Zeithaml, \& Berry, 1988). Factor analysis has been used to group individual attribute statements into component areas (e.g., Carman, 1990; Cronin \& Taylor, 1992; Parasuraman, Zeithaml, \& Berry, 1988). The relationship between SERVQUAL measures and purchase intentions and on the types of aggregation that lead to consistent overall ratings has been examined (e.g., Bitner, 1990; Bolton \& Drew, 1991a, b; Cronin \& Taylor, 1992; Danaher, 1997; Sampson, 1999).

The study reported here differs by focusing on separate attributes associated with customer perceptions of store features without generating an overall index. Furthermore, it models ideal, actual, and the difference as functions of socioeconomic variables. The application utilizes a censored dependent variable framework, thereby addressing the problem of skewed distributions (Hurley \& Estelami, 1998).

\section{A SERVQUAL SURVEY FOR GREEN GROCERS}

Previous surveys have found common criteria (quality, pricing, convenience, freshness, and selection) used by food shoppers at direct outlets (e.g., Brooker \& Eastwood, 1991; Brooker, Eastwood, \& Orr, 1986, 1988; Eastwood, Brooker, \& Gray 1998; Govindasamy \& Nayga, 1996; Govindasamy, Italia, \& Thatch, 1998; Packer Fresh Trends, 1998; Rhodus, Schwartz, \& Hoskins, 1994; Schatzear, Tilley, \& Mosel, 1989). Satisfaction also depends on experiences with employees and the checkout process (Dabholkar, Thorpe, \& Rentz, 1996; Parasuraman, Seithaml, \& Berry, 1988; Zeithaml, Parasuraman, \& Berry, 1990). These studies generated overall indices to compare stores.

There were 24 feature statements in the instrument developed for the present survey (the questionnaire is available from the authors). Five-point scales were used for each of the 24 statements. With respect to ideal ratings, $1=$ "not very important to me" and $5=$ "very important to me." Actual ratings were based on trips to stores and were phrased in terms of how well expectations were met with $1=$ "not very well" to 5 = "very well."

There is no unique set of SERVQUAL statements, as they have to change with the type of enterprise and problem under study. The statements described here were based on Bearden and Netemeyer (1999) and Behe and Barton (2000) and modified in light of fresh produce preference surveys (Brooker, Eastwood, \& Orr, 1988; Govindasamy et al., 1998; Packer Fresh Trends, 1998). The number of statements reflects trade-offs between instrument length and features to include. Eight feature subgroups were created. One question dealt with quality and was included because consumer surveys had found this to be the most important feature for selecting where they shopped and in order to present a relevant range of store features. One statement referred to hours of operation. ${ }^{2}$ There were two statements about signs. One for how appealing the signs were, and the other referred to the labeling of locally grown produce. Two pricing statements referred to the accuracy of pricing, billing and orders, and the other dealt with how clearly items were marked. Three aspects of the physical appearance (modern-looking facility, visually appealing, and aisles) were included. Based on open ended statements on the surveys cited above, three types of additional products to sell were milk and eggs, homemade bakery products,

\footnotetext{
${ }^{2}$ In other settings, additional statements could be included for days and opening and closing times.
} 
TABLE 1. SERVQUAL Feature Groups (Listed in the Order They Appeared in the Questionnaire)

\begin{tabular}{|c|c|c|}
\hline $\begin{array}{l}\text { Ques. } \\
\text { No. }\end{array}$ & Statement & $\begin{array}{l}\text { Feature } \\
\text { Group }\end{array}$ \\
\hline 1. $\mathrm{h}$ & ties (buildings, displays, etc.) & Appearance \\
\hline 2. is & & Appearance \\
\hline 3. $h$ & ourteous & Employees \\
\hline 4. $\mathrm{h}$ & ns and posters & Signs \\
\hline 5. a & & Variety \\
\hline 6. $\mathrm{s}$ & answering customer questions & Employees \\
\hline 7. ir & g, customer bills, and orders & Pricing \\
\hline 8. $\mathrm{h}$ & walk through & Appearance \\
\hline 9. $\mathrm{h}$ & illing to help customers & Employees \\
\hline 10. $\mathrm{h}$ & the knowledge to answer customer questions & Employees \\
\hline 11. $\mathrm{g}$ & l attention & Employees \\
\hline 12. $\mathrm{h}$ & hours & Hours \\
\hline 13. a & kery products & Variety \\
\hline 14. $\mathrm{c}$ & f all the items for sale & Information \\
\hline 15. $\mathrm{c}$ & f items & Pricing \\
\hline 16. $\mathrm{e}$ & rvice to customers & Employees \\
\hline 17. e & dle customers complaints directly and quickly & Employees \\
\hline 18. s & e fresh produce & Quality \\
\hline 19. c & vn produce & Signs \\
\hline 20. $\mathrm{p}$ & or availability of locally grown produce & Information \\
\hline 21. $\mathrm{h}$ & and posters that provide useful information & Information \\
\hline 22. $\mathrm{h}$ & s what local foods are currently available & Information \\
\hline 23. a & & Variety \\
\hline 24. if & $\mathrm{m}$, the store shows sincere interest in solving it & Employees \\
\hline
\end{tabular}

and special coffees were included. Produce information provided at the point of purchase included clear labels, expected dates for the availability of locally grown produce, useful signage within the outlet and on the roadside. There were eight statements focusing on interactions between customers and employees, covering courtesy, interest in answering questions, willingness to help, knowledge, individual attention, prompt service, complaint handling, and interest in solving problems. Table 1 lists the statements in the order they appeared in the survey.

\section{THE GREEN GROCER SURVEY}

A list of all the green grocers operating in 1999 in Tennessee was prepared using the Yellow Pages for the larger metropolitan areas and a computerized directory of businesses that could be sorted on the basis of SIC codes and location. Interviews with managers of the stores provided information about operating characteristics, physical features, and sales information. Based on these data, seven outlets were chosen for the study to represent the variety of green grocers operating in the state. They were open year-round, had fixed buildings, and parking was on-site. The outlets carried locally grown produce during the six month harvest season, which typically begins in May and extends through October. Three stores were located in the second through the fourth largest metropolitan 
areas in the state. The other four were located in smaller metropolitan areas. All seven stores agreed to participate in surveys of their shoppers.

In the summer of 2000, one thousand questionnaires were distributed to each outlet, and the stores then distributed the surveys to shoppers. Prepaid envelopes were included with the questionnaires, so they could be returned easily. An insufficient number of surveys was received from the outlet in the second largest metropolitan area, so only six stores were included in the analyses described below. A total of 1,118 questionnaires were returned from the six outlets for an overall response rate of $19 \%$.

Table 2 presents descriptive statistics of the sample by store. The composition of the sample is consistent with the profile of fresh produce consumers (Putnam \& Allshouse, 1999). The majority of consumers were 35 and older. They were predominantly college educated people. Most had no dependents, and the majority were married. Over $50 \%$ had incomes of $\$ 25,000$ to $\$ 75,000$. Tests of independence were conducted with each group of demographics (e.g., the five age groups versus the stores). There were only seven instances of significant differences between the store averages and the overall averages (age 55 to 64 with store 5, college graduate with store 3, single and dependents with stores 1 and 6, married and dependents with store 5, and store 5 for income groups $\$ 50,000$ to $\$ 74,999$ and $\$ 75,000$ to $\$ 99,999)$. An implication is that typical shoppers at the outlets were quite similar. Another is that the stores were all focused on similar target markets.

\section{GREEN GROCER SERVQUAL RESULTS}

Responses were analyzed by feature subgroup. Since quality and hours had one feature statement each, these were the values used. For the six remaining subgroups, averages for subgroup statements by respondent were generated. Three analyses were conducted for each subgroup average across respondents. One for the ideal ratings, one for the actual ratings, and one for the difference between the actual and ideal, where a positive (negative) difference reflected a feature having a higher (lower) actual rating than the respective ideal value. Averages for the first two ranged from one to five. Averages for the third ranged from minus four to plus four.

Table 3 presents the average SERVQUAL scores for the entire sample and by store. They are the mean scores across respondents for the eight subgroups. The subgroups are listed in descending order according to their ideal scores for all respondents. Subgroup ranks are in parentheses. Tests of independence were conducted between the store averages and the overall average within each subgroup, and significant differences are noted. As suggested by the average ideal and actual values for the first four subgroups being close to their upper limits, their distributions were negatively skewed, which is not uncommon (Hurley \& Estelami, 1998).

Quality was the most important ideal attribute overall. Employees, pricing, and hours formed a cluster below quality. Information, signs, and appearance comprised a second cluster. Variety was last, which was not unexpected because patrons, presumably, were at the outlets to buy fresh produce. Inspection of the table suggests respondents had similar ideal valuations across outlets. Among the top four ideal subgroups, no significant differences by store were found, and within the other four there were only seven significant differences out of a possible 24 . These results suggest respondents are fairly homogeneous with respect to their ideal criteria for rating store features.

Employees had the highest actual average score, followed by pricing and hours, then quality. The next three formed a cluster, and the ordering is the same with the ideal scores. 
TABLE 2. Socioeconomic Variables by Store (Percentage Distributions)

\begin{tabular}{|c|c|c|c|c|c|c|c|}
\hline \multirow{2}{*}{$\begin{array}{l}\text { Socioeconomic } \\
\text { Variables }\end{array}$} & \multirow[b]{2}{*}{ Total } & \multicolumn{6}{|c|}{ Stores } \\
\hline & & 1 & 2 & 3 & 4 & 5 & 6 \\
\hline \multicolumn{8}{|l|}{ Age } \\
\hline 15 to 24 & 1.2 & 2.0 & 1.2 & 0.6 & 0.7 & 2.2 & 1.9 \\
\hline 25 to 34 & 5.2 & 3.1 & 3.7 & 8.0 & 4.9 & 8.6 & 5.6 \\
\hline 35 to 44 & 13.9 & 15.3 & 8.9 & 14.1 & 14.6 & 20.4 & 20.4 \\
\hline 45 to 54 & 23.5 & 21.4 & 21.2 & 20.3 & 24.3 & $36.6^{*}$ & 24.1 \\
\hline 55 to 64 & 23.5 & 28.6 & 29.8 & 19.0 & 21.2 & 16.1 & 19.4 \\
\hline $65 \&$ up & 32.6 & 29.6 & 35.3 & 38.0 & 34.4 & 16.1 & 28.7 \\
\hline \multicolumn{8}{|l|}{ Gender } \\
\hline Female & 78.1 & 81.4 & 70.6 & 78.1 & 82.9 & 77.2 & 85.9 \\
\hline Male & 21.9 & 18.6 & 29.5 & 22.0 & 17.1 & 22.8 & 14.2 \\
\hline \multicolumn{8}{|l|}{ Education } \\
\hline Some H.S. & 5.2 & 4.2 & 6.3 & 1.2 & 7.0 & 5.4 & 3.9 \\
\hline H.S. Grad & 23.8 & 33.3 & 30.1 & 9.8 & 18.7 & 25.8 & 29.8 \\
\hline Some College & 22.0 & 18.8 & 22.2 & 18.4 & 24.7 & 19.4 & 25.0 \\
\hline College Grad & 49.1 & 43.8 & 41.5 & $70.6^{*}$ & 49.7 & 49.5 & 41.4 \\
\hline \multicolumn{8}{|l|}{ Household Status } \\
\hline Single \& Dependents & 5.4 & $0.0^{*}$ & 3.4 & 5.5 & 6.0 & 4.4 & $15.5^{*}$ \\
\hline Married \& Dependents & 30.9 & 33.3 & 28.4 & 23.9 & 31.3 & $47.8^{*}$ & 31.1 \\
\hline Single No Dependents & 16.3 & 12.5 & 15.7 & 27.0 & 14.8 & 6.5 & 17.5 \\
\hline Married No Dependents & 47.5 & 54.2 & 52.5 & 43.6 & 47.9 & 41.3 & 35.9 \\
\hline \multicolumn{8}{|l|}{ Household Size } \\
\hline 1 Person & 15.9 & 9.4 & 16.8 & 23.9 & 13.3 & 5.5 & 22.3 \\
\hline 2 People & 53.8 & 55.2 & 58.1 & 49.7 & 57.2 & 42.9 & 45.6 \\
\hline 3 People & 15.2 & 27.1 & 12.1 & 12.9 & 14.4 & 19.8 & 15.5 \\
\hline 4 People & 10.5 & 4.2 & 9.3 & 9.8 & 11.9 & 19.8 & 9.7 \\
\hline 5 People & 3.8 & 3.1 & 2.5 & 3.1 & 2.9 & 11.0 & 5.8 \\
\hline 6 People & 0.6 & 1.0 & 0.6 & 0.0 & 0.4 & 1.1 & 1.0 \\
\hline 7 or more & 0.3 & 0.0 & 0.6 & 0.6 & 0.0 & 0.0 & 0.0 \\
\hline \multicolumn{8}{|l|}{ Household Income } \\
\hline$<\$ 25,000$ & 14.7 & 20.0 & 12.5 & 14.1 & 13.5 & 12.8 & 22.2 \\
\hline$\$ 25,000$ to $\$ 49,999$ & 35.1 & 32.5 & 39.0 & 31.7 & 35.9 & 28.2 & 34.4 \\
\hline$\$ 50,000$ to $\$ 74,999$ & 25.7 & 20.0 & 24.3 & 24.7 & 28.2 & $30.8^{*}$ & 25.6 \\
\hline$\$ 75,000$ to $\$ 99,999$ & 11.1 & 12.5 & 10.3 & 12.0 & 9.8 & $18.0 *$ & 8.9 \\
\hline$\$ 100,000$ to $\$ 124,999$ & 5.5 & 7.5 & 4.8 & 6.3 & 6.5 & 3.9 & 3.3 \\
\hline$\$ 125,000+$ & 7.9 & 7.5 & 9.2 & 1.1 & 6.1 & 6.4 & 5.6 \\
\hline Sample Size & 1,118 & 101 & 351 & 167 & 295 & 94 & 110 \\
\hline
\end{tabular}

*Significant difference between the respective store and the all store average.

Variety was last. Another aspect of the actual scores is that there are more significant differences among the stores. Store 6 is frequently below average, and stores 2 and 5 above. Such patterns are consistent with variations among features of individual outlets.

Differences are actual minus ideal average scores, so positive (negative) values indicate the respective feature more (less) than meets respondents' expectations. Ranks for each attribute by store for the actual, ideal, and difference averages are in parentheses. 
TABLE 3. Average SERVQUAL Actual, Ideal, and Difference Scores and Rankings

\begin{tabular}{|c|c|c|c|c|c|c|c|}
\hline & \multirow[b]{2}{*}{ All } & \multicolumn{6}{|c|}{ Store } \\
\hline & & 1 & 2 & 3 & 4 & 5 & 6 \\
\hline \multicolumn{8}{|l|}{ Quality } \\
\hline Actual & $4.42(4)$ & $4.34(3)$ & $4.63(2) *$ & $4.28(4)$ & $4.38(4)$ & $4.52(3)$ & $4.06(4) *$ \\
\hline Ideal & $4.80(1)$ & $4.81(1)$ & $4.83(1)$ & 4.71(1) & 4.81(1) & $4.80(1)$ & $4.78(1)$ \\
\hline Difference & $-.38(1)$ & $-.47(1)$ & $-.20(1)$ & $-.43(1)^{*}$ & $-.43(1)^{*}$ & $-.28(1)$ & $-.72(1)^{*}$ \\
\hline \multicolumn{8}{|l|}{ Employees } \\
\hline Actual & $4.56(1)$ & $4.62(1)$ & $4.78(1)^{*}$ & $4.52(1)$ & $4.43(3)$ & $4.67(1)$ & $4.10(3)^{*}$ \\
\hline Ideal & $4.59(2)$ & $4.60(3)$ & $4.70(2)$ & $4.48(3)$ & $4.55(4)$ & $4.64(2)$ & $4.43(4)$ \\
\hline Difference & $-.03(5)$ & $.02(6)$ & $.08(4) *$ & $.04(5)$ & $-.12(3)$ & $.03(4)$ & $-.33(4)$ \\
\hline \multicolumn{8}{|l|}{ Pricing } \\
\hline Actual & $4.45(2)$ & $4.15(4) *$ & $4.62(3) *$ & $4.45(2)$ & $4.47(2)$ & $4.34(4)$ & $4.24(1)^{*}$ \\
\hline Ideal & $4.59(2)$ & $4.58(4)$ & $4.66(3)$ & $4.49(2)$ & $4.63(2)$ & $4.49(4)$ & $4.53(4)$ \\
\hline Difference & $-.14(2)$ & $-.43(2)^{*}$ & $-.04(2) *$ & $-.04(3) *$ & $-.16(2)$ & $-.15(2)$ & $-.29(5)$ \\
\hline \multicolumn{8}{|l|}{ Hours } \\
\hline Actual & $4.45(2)$ & $4.40(3)$ & $4.53(4)$ & $4.36(3)$ & $4.48(1)$ & $4.58(2)$ & $4.16(2)^{*}$ \\
\hline Ideal & $4.54(4)$ & $4.63(2)$ & $4.51(4)$ & $4.47(4)$ & $4.58(3)$ & $4.54(3)$ & $4.59(2)$ \\
\hline Difference & $-.09(3)$ & $-.23(3) *$ & $.02(3)$ & $-.11(3)$ & $-.10(4)$ & $.04(5)$ & $-.43(2) *$ \\
\hline \multicolumn{8}{|l|}{ Information } \\
\hline Actual & $3.82(7)$ & $3.62(7) *$ & $4.12(6)^{*}$ & $3.47(7)^{*}$ & $3.88(7)$ & $3.82(6)$ & $3.34(7) *$ \\
\hline Ideal & $3.88(5)$ & $3.83(6)$ & $3.98(5)$ & $3.65(6)^{*}$ & $3.93(5)$ & $3.85(5)$ & $3.77(7)$ \\
\hline Difference & $-.06(4)$ & $-.21(4) *$ & $.14(5) *$ & $-.18(2)$ & $-.05(5)$ & $-.03(3)$ & $-.43(2) *$ \\
\hline \multicolumn{8}{|l|}{ Signs } \\
\hline Actual & $4.02(5)$ & $3.91(5)$ & $4.16(5)$ & $3.93(5)$ & $4.12(4)$ & $3.77(7)$ & $3.73(6)$ \\
\hline Ideal & $3.87(6)$ & $3.90(5)$ & $3.92(6)$ & $3.66(3) *$ & $3.93(5)$ & $3.71(6)^{*}$ & $3.97(6)$ \\
\hline Difference & $.15(6)$ & $.01(5) *$ & $.24(6)$ & $.27(6)$ & $.19(7)$ & $.06(6) *$ & $-.24(6) *$ \\
\hline \multicolumn{8}{|l|}{ Appearance } \\
\hline Actual & $3.90(6)$ & $3.83(6)$ & $4.02(7)$ & $3.79(6)$ & $3.80(8)$ & $3.92(5)$ & $4.02(5)$ \\
\hline Ideal & $3.60(7)$ & $3.51(7)$ & $3.60(7)$ & $3.27(7) *$ & $3.74(7)$ & $3.41(7) *$ & $3.99(5)$ \\
\hline Difference & $.30(7)$ & $.32(7)$ & $.42(7)$ & $.52(7)$ & $.06(6) *$ & $.51(7)$ & $.03(7) *$ \\
\hline \multicolumn{8}{|l|}{ Variety } \\
\hline Actual & $3.61(8)$ & $3.41(8) *$ & $3.65(8)$ & $3.43(8) *$ & $4.01(6) *$ & $3.20(8) *$ & $2.93(8) *$ \\
\hline Ideal & $2.54(8)$ & $2.56(8)$ & $2.43(8)$ & $2.57(8)$ & $2.84(8) *$ & $1.86(8) *$ & $2.53(8)$ \\
\hline Difference & $1.07(8)$ & $.85(8) *$ & $1.22(8)$ & $.86(8) *$ & $1.17(8)$ & $1.34(8) *$ & $.40(8) *$ \\
\hline
\end{tabular}

Note: Numbers in parentheses are the ranks of the feature subgroups' actual, ideal, and difference averages within the respective columns. Actual and ideal ranks are in descending order, and the difference is in ascending order. * denotes significant differences between the store average and the respective average for all stores.

Quality had the lowest difference. Pricing was next, although its average value was less than half that of quality. Hours, employees, and information also had negative averages, but they were closer to meeting the typical respondent's ideal. Signs, appearance, and variety had positive differences.

Although quality was the most important ideal feature, the negative differences suggest there was room for improvement. Care should also be taken in pricing produce in terms of signage and accuracy. Outlets were close to meeting expectations with respect to employee interactions with shoppers, hours of operation, and information provided. The 
variety difference indicates customers are not looking for milk, eggs, bakery products, or coffee at these stores, but the stores were more than meeting variety expectations. Stores 2 and 5 had positive differences for every feature subgroup, whereas store 6 tended to have more significant negative differences.

\section{MODELING IDEAL, ACTUAL, AND DIFFERENCE SCORES}

Assume ideal and actual scores represented points on continuous rating scales. The negatively skewed distributions of respondent ratings are consistent with the data representing censored observations, and with the underlying distributions being normally distributed. Given this setting, the three scores represent double censored variables (Greene, 2003).

Utility maximizing behavior on the part of food shoppers involves equating the values of the last dollar spent on goods and services, or the ratio of the marginal utilities to respective prices. Beginning with the work of Stigler (1961), the denominator has been shown to represent the opportunity cost of purchasing. This opportunity cost encompasses more than the market price. Other costs include information acquisition, shopping time, and risk that products do not meet expectations. All of these are directly determined by outlet characteristics. Valuations of attributes, as a result, depend on the socioeconomic characteristics of consumers. Consequently, the scores were considered to be functions of socioeconomic characteristics. Dummy variables for outlets were included to allow for differences in valuations by store. Independent variables are presented in Table 4. Education, age, and income were coded as the presence/absence of the various categories. Separate regressions for each subgroup were estimated under the assumptions that a person's scores were determined independently and that there was no reason to assume a common set of independent variables affected the eight feature subgroups.

Initial regressions were estimated using all the dummy variables included in Table 4. Variables with insignificant coefficients were deleted on a one-by-one basis. The loglikelihood values, coefficients, and their standard errors were compared to those of earlier regressions. If there was little change in the overall fit, remaining coefficients, and standard errors, the variables that had been deleted were left out of subsequent estimations. This process was followed in an effort to minimize possible omitted variable biases and the inclusion of extraneous variables (Greene). The resulting equations are presented in Tables 5-7 for the ideal, actual, and difference models.

The chi square values for each equation lead to inferences that significant overall fits have been found. The signs of the coefficients reflect the direction of causality. A positive (negative) significant coefficient leads to the inference that the respective actual, ideal, or difference rating increases (decreases) with the presence of the respective independent variable. Since none of the independent variables is continuous, no marginal effects are presented.

Table 5 presents the estimated ideal feature equations. No solution was found for the quality feature. With respect to the other subgroups, there were relatively few store impacts. Respondents who were 45 and older tended to give higher ratings of signs, and the two oldest age categories had higher ideal valuations of appearance and variety. Women had positive coefficients in three instances: employees, price, and hours. College graduates gave lower ideal scores for signs, information, and appearance and higher ones to variety. Income coefficients were mostly negative, where significant. With respect to price, they become more negative as income categories rise. Three income coefficients for hours are 
TABLE 4. Variable Definitions

\begin{tabular}{|c|c|c|}
\hline Variable & Definition & Mean \\
\hline \multicolumn{3}{|l|}{ Education } \\
\hline Ed1* & $=1$ for some high school, $=0$ otherwise. & $5.21 \%$ \\
\hline $\mathrm{Ed} 2$ & $=1$ for high school graduate, $=0$ otherwise. & $23.77 \%$ \\
\hline Ed3 & $=1$ for some college,$=0$ otherwise. & $21.97 \%$ \\
\hline Ed4 & $=1$ for college graduate,$=0$ otherwise & $49.05 \%$ \\
\hline \multicolumn{3}{|l|}{ Age } \\
\hline Age1* & $=1$ for 15 to $24,=0$ otherwise. & $1.21 \%$ \\
\hline Age2 & $=1$ for 25 to $34,=0$ otherwise. & $5.20 \%$ \\
\hline Age3 & $=1$ for 35 to $44,=0$ otherwise. & $13.94 \%$ \\
\hline Age4 & $=1$ for 45 to $54,=0$ otherwise. & $23.51 \%$ \\
\hline Age5 & $=1$ for 55 to $64,=0$ otherwise. & $23.51 \%$ \\
\hline Age6 & $=1$ for 65 and over, $=0$ otherwise. & $32.62 \%$ \\
\hline \multicolumn{3}{|c|}{ Marital Status } \\
\hline Satus1* & $=1$ for single with dependents, $=0$ otherwise. & $5.37 \%$ \\
\hline Status2 & $=1$ for married with dependents, $=0$ otherwise. & $30.89 \%$ \\
\hline Status3 & $=1$ for single with no dependents, $=0$ otherwise. & $16.29 \%$ \\
\hline Status4 & $=1$ for married with no dependents, $=0$ otherwise. & $47.46 \%$ \\
\hline \multicolumn{3}{|l|}{ Gender } \\
\hline Female & $=1$ for female,$=0$ male. & $78.06 \%$ \\
\hline \multicolumn{3}{|c|}{ Household Size } \\
\hline Size & $=$ the number of household members. & 2.36 \\
\hline \multicolumn{3}{|l|}{ Income } \\
\hline $\mathrm{I} 1 *$ & $=1$ if $\$ 25,000$ or less, $=0$ otherwise. & $14.66 \%$ \\
\hline $\mathrm{I} 2$ & $=1$ if $\$ 25,000$ to $\$ 49,999,=0$ otherwise. & $35.06 \%$ \\
\hline $\mathrm{I} 3$ & $=1$ if $\$ 50,000$ to $\$ 74,999,=0$ otherwise. & $25.69 \%$ \\
\hline I4 & $=1$ if $\$ 75,000$ to $\$ 99,999,=0$ otherwise. & $11.24 \%$ \\
\hline I5 & $=1$ if $\$ 100,000$ to $\$ 124,999,=0$ otherwise. & $5.51 \%$ \\
\hline I6 & $=1$ if $\$ 125,000$ or more,$=0$ otherwise. & $7.94 \%$ \\
\hline \multicolumn{3}{|l|}{ Stores } \\
\hline $\mathrm{S} 1 *$ & $=1$ if respondent came from store $1,=0$ otherwise. & $9.03 \%$ \\
\hline $\mathrm{S} 2$ & $=1$ if respondent came from store $2,=0$ otherwise. & $31.40 \%$ \\
\hline S3 & $=1$ if respondent came from store $3,=0$ otherwise. & $14.94 \%$ \\
\hline S4 & $=1$ if respondent came from store $4,=0$ otherwise. & $26.39 \%$ \\
\hline S5 & $=1$ if respondent came from store $5,=0$ otherwise. & $8.41 \%$ \\
\hline S6 & $=1$ if respondent came from store $6,=0$ otherwise. & $9.84 \%$ \\
\hline
\end{tabular}

positive and increasing. Married respondents tended to give higher ratings for price and information.

Actual ratings regression results are found in Table 6 . There are significant store coefficients in 22 of the 40 possible instances. Store 2's coefficients are positive for six of the eight subgroups, and store 6 has negative coefficients for five. Store 5 is associated with positive effects on actual scores of quality and information and negative effects on signs and variety. Store 6 has negative coefficients for five subgroups. Age category coefficients are significant in only two instances, of which one was positive and one was 


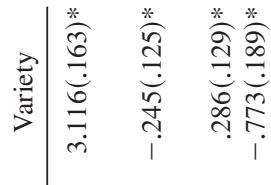

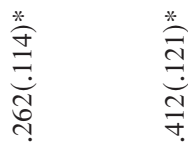

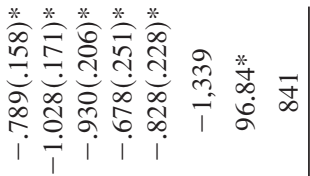

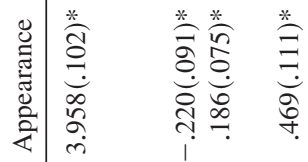

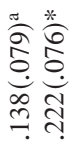

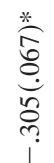

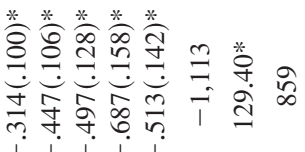

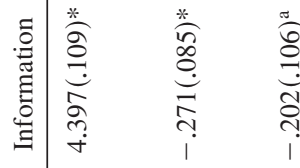

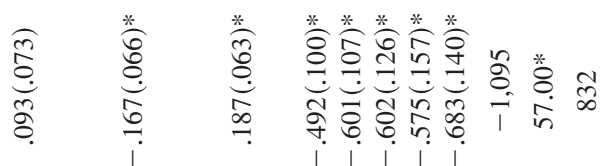

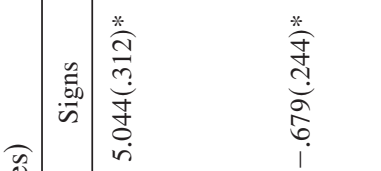

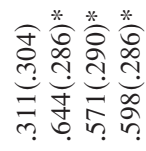

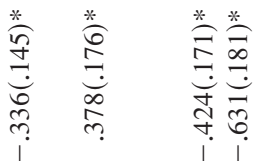
†ำ

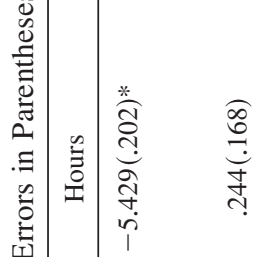
荬

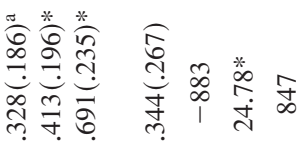

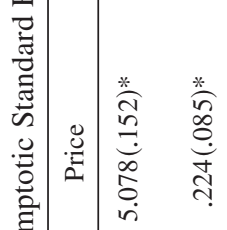

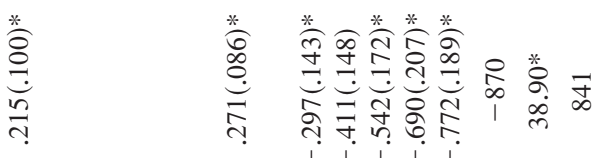

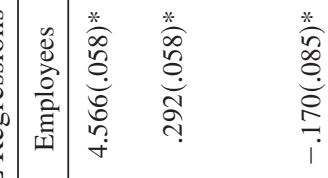
葛

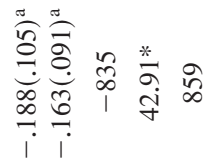

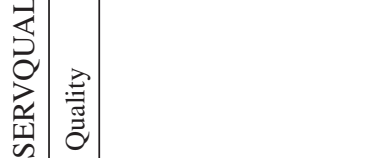
这这

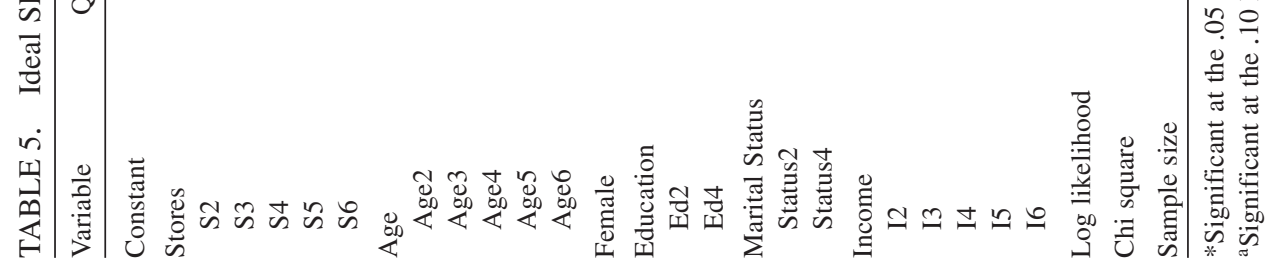


MARKETING STRATEGIES FOR GREEN GROCERS

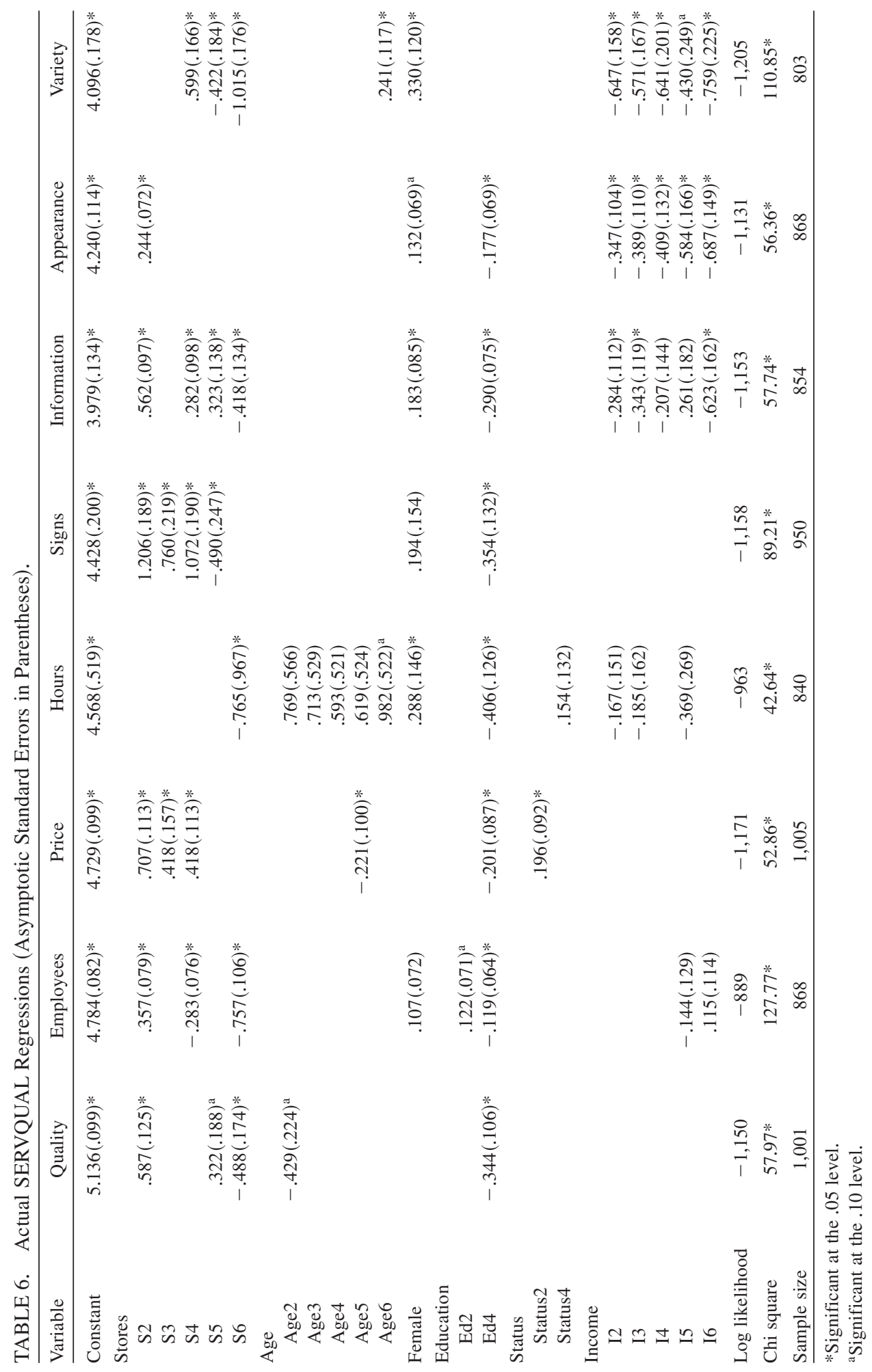




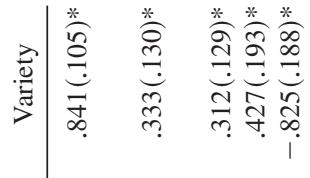

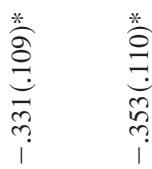

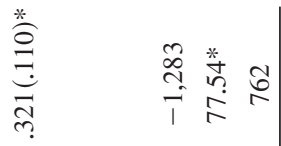

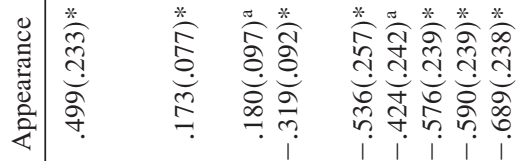

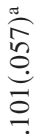

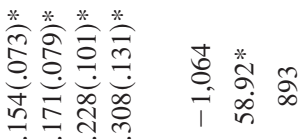

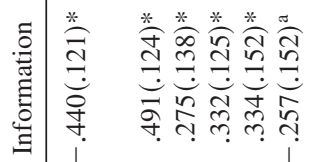

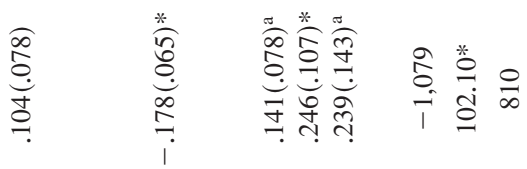

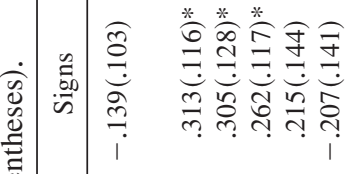

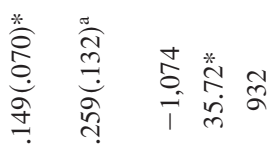

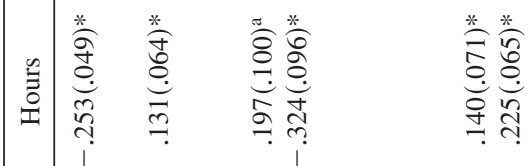

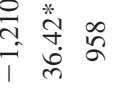

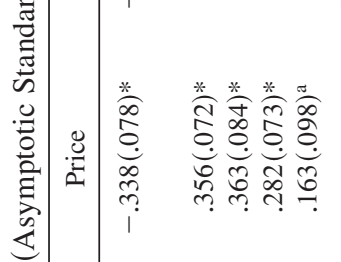
(x)

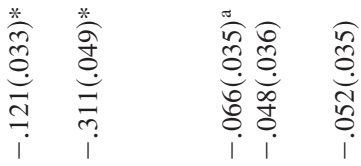

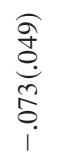

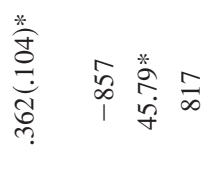

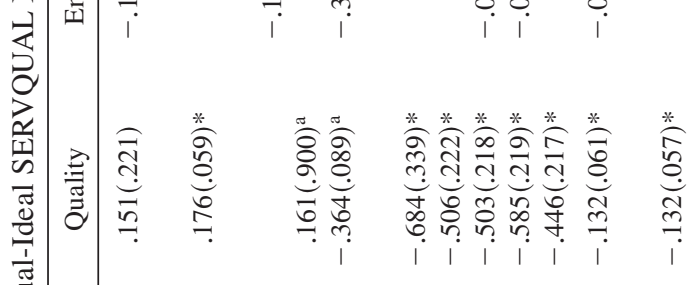

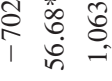


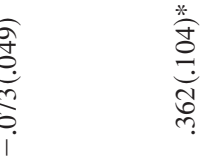

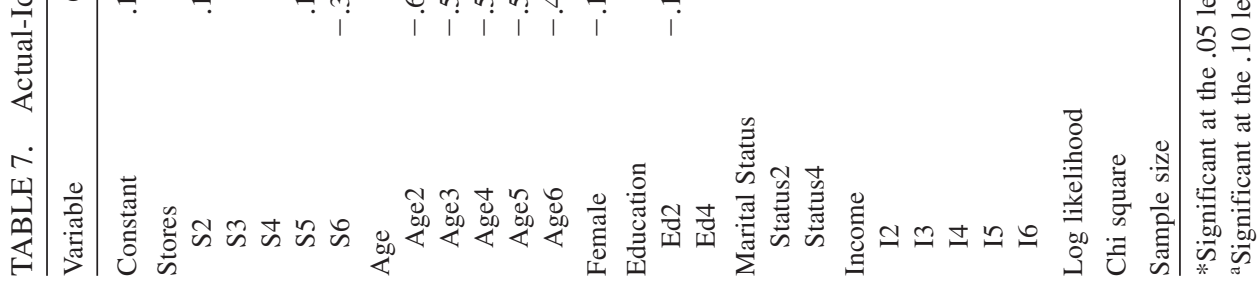

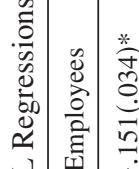


negative. Women tended to give higher ratings for hours, information, appearance, and variety. College graduates gave significantly lower actual scores for all subgroups except variety. Married respondents with dependents had a positive coefficient for price. Income categories had negative effects on actual ratings of information, appearance, and variety.

Estimates of the difference equations are presented in Table 7. Coefficients are interpreted as to whether the difference between the respective actual minus the ideal ratings is increasing. Stores 2 and 6 have fairly consistent patterns of coefficients. The former has positive effects in six of eight instances, and the latter has negative effects in all but one. Every age category effect is negative in the quality and appearance equations, as well as Age4 being negative in the employee equation and Age6 in the variety equation. Age 5 and Age6 had positive coefficients in the hours equation. Women gave significantly lower quality difference scores. Those who had only completed high school gave lower difference scores for quality and variety. Respondents who were married with no dependents gave lower difference scores for information. Income effects were positive when they were significant.

\section{MARKETING IMPLICATIONS}

Analyses of the responses to the SERVQUAL questionnaire illustrate the potential of this type of survey for consumer friendly/oriented stores. The analysis described here has focused on a new way of analyzing the information. In particular, a respondent's average SERVQUAL score was generated for each feature subgroup for the ideal, actual, and difference scales. Then, these scores were considered to be functions of the outlets in the survey and socioeconomic variables.

The hypothesis that the determinants of store feature ratings vary by feature subgroup is supported, as is the hypothesis that the determinants of ideal, actual, and difference scores are not the same. In addition, ideal ratings tend not to be store specific, whereas, the actual and difference scores do change by outlet. Since the same type of store venue is involved (i.e., green grocers), it is not surprising to find that the ideal ratings tend to be similar, whereas the actual and difference scores tend to be store related.

The two types of analyses can provide useful information. One type focuses on the average scores across respondents by subgroup feature by store. Features for which an outlet is meeting expectations are associated with difference scores close to zero. A negative difference score suggests the respective store is not meeting the average shopper's ideal valuation, and when compared to the store's ideal average for the respective feature, managers have an indication of where the outlet is falling short and how that feature is rated by the typical customer. Such an approach can help prioritize areas for increased customer satisfaction.

Regression analysis also provides useful marketing insights which dovetail with the first type of analysis. That is, given the priority feature areas, the significant demographic coefficients point to target shoppers to reach to improve the average actual scores and/or to impact the difference (actual-ideal) in a favorable manner. For example, based on the negative differences, the typical consumer's actual experiences were less than the ideal ratings for produce quality, prices, hours of operation or product information for any outlet. Results among the stores are mixed for the employees and signs subgroups. For appearance and variety subgroups, all six stores received positive difference ratings by their typical customer. While managers may not be able to lower prices or increase hours of operation without serious cost considerations, the negative quality image and the negative 
information weakness may be addressed immediately with minimal expense. To improve quality as much as possible with existing supplies, simply instructing employees to pick over display gins on a regular basis to remove damaged or spoiled produce could be of considerable help. Also, use of existing signs to improve information could be quickly accommodated to provide information about produce items, such as expected harvest dates for locally grown items and how to select different fruits and vegetables. Employees could also be reminded that women value service. Outlets located in higher income areas should pay more attention to employees' customer service.

\section{ACKNOWLEDGMENT}

Funding for this study was from a USDA/CSREES/FSMIP grant.

\section{REFERENCES}

Anderson, E.W., Fornell, C., \& Lehman, D.R. (1994). Customer satisfaction, market share, and profitability: Findings from Sweden. Journal of Marketing, 58, 53-66.

Bearden, W.O., \& Netemeyer, R.B. (1999). Handbook of marketing scales (2nd ed.). Thousand Oaks, CA: SAGE Publications.

Behe, B., \& Barton, S. (2000). Consumer perceptions of product and service quality attributes in six U.S. states. Journal of Environmental Horticulture, 18(2), 71-78.

Bitner, M.J. (1990). Evaluating service encounters: The effects of physical surroundings and employee response. Journal of Marketing, 54, 69-82.

Bolton, R.N., \& Drew, J.H. (1991a). A longitudinal analysis of the impact of service changes on customer attitudes. Journal of Marketing, 55, 1-9.

Bolton, R.N., \& Drew, J.H. (1991b). A multistage model of customers' assessments of service quality and value. Journal of Consumer Research, 17, 375-384.

Bouman, M., \& van der Wiele, T. (1992). Measuring service quality in the car service industry: Building and testing an instrument. International Journal of Service Industry Management, 3(4), $4-16$.

Brooker, J.R., \& Eastwood, D.B. (1991). State promotional programs of locally grown fresh produce and consumer response to special displays in supermarkets: A case study in Tennessee. Tennessee Agricultural Experiment Station Bulletin 677.

Brooker, J.R., Eastwood, D.B., \& Orr, R.H. (1986). Consumer stated preferences for fresh fruits and vegetables. University of Tennessee Agriculture Experiment Station. Research Report 86-06.

Brooker, J.R., Eastwood, D.B., \& Orr, R.H. (1988). State logos for fresh and processed foods: A case study for consumers in Knox County, Tennessee. Tennessee Agricultural Experiment Station Bulletin 661.

Calvin, L., Cook, R., Denbaly, M., Dimitri, C., Glazer, L., Handy, C., Jekanowski, M., Kaufman, P., Krisoff, B., Thompson, B., \& Thornsbury, S. (2001). U.S. fruit and vegetable marketing: Emerging trade practices, trends, and issues. USDA/ERS Agricultural Economic Report 795.

Carman, J.M. (1990). Consumer perceptions of service quality: An assessment of the SERVQUAL dimensions. Journal of Retailing, 66(1), 33-55.

Colley, J.L. (Ed.) (1996). Case studies in service operations. New York: Duxbury Press.

Cronin, J.J., Jr., \& Taylor, S.A. (1992). Measuring service quality: A reexamination and extension. Journal of Marketing, 56, 55-68.

Dabholkar, A., Thorpe, D.L., \& Rentz, J.O. (1996). A measure of service quality for retail stores: Scale development and validation. Journal of the Academy of Marketing Science, 24(1), 3-16.

Danaher, P.J. (1997). Using conjoint analysis to determine the relative importance of service attributes measured in customer satisfaction surveys. Journal of Retailing, 73(2), 235-260.

Dimitri, C., Tegene, A., \& Kaufman, P. (2003). U.S. fresh produce markets: Marketing channels, trade practices, and retail pricing behavior. USDA Agricultural Report 825.

Eastwood, D.B., Brooker, J.R., Eastwood, D.B., \& Gray, M.D. (1998). Consumer attitudes, perceptions, and behaviors about locally grown fresh produce: A case study of six locations in Tennessee. Tennessee Agricultural Experiment Station Research Report 98-09. 
Fick, G.R., \& Ritchie, J.R.B. (1991). Measuring service quality in the travel and tourism industry. Journal of Travel Research, 30, 2-9.

Govindasamy, R., Italia, J., Pingali, A., \& Thatch, D. (1998). Consumer response to state-sponsored marketing programs: The case of Jersey Fresh. New Jersey Agricultural Experiment Station, Cooperative Extension, Rutgers University. P-02137-2-98.

Govindasamy, R., \& Nayga, R. (1996). Characteristics of farmer-to-consumer direct market customers: An overview. Journal of Extension, 34(4), 1-5.

Greene, W.H. (2003). Econometric analysis, 5th edition. Englewood Cliffs, NJ: Prentice Hall Publishers.

Hudson, J.T., Behe, B.K., Ponder, H.G., \& Barrick, W.E. (1998). Consumer perceptions and expectations of garden center product and service quality. Journal of Environmental Horticulture, $15(1), 12-15$.

Hurley, R.F., \& Estelami, H. (1998). Alternative indexes for monitoring customer perceptions of service quality: A comparative evaluation in a retail context. Journal of the Academy of Marketing Science, 26(3), 209-221.

Lawless, G., Cropp, R., Hedrickson, J., \& Stevenson, G.W. (1996). The farmer-food buyer dialogue project. University of Wisconsin Center for Cooperatives.

Lovelock, C.H. (1992). Managing services: Marketing, operations, and human resources. Englewood Cliffs, NJ: Prentice-Hall.

McDaniel, J.R., \& Lourgand, M.A. (1994). Real estate brokerage service quality: An examination. Journal of Real Estate Research, 9, 339-351.

Mersha, T., \& Adlakha, V. (1992). Attributes of service quality: The consumers' perspective. International Journal of Service Industry Management, 3(3), 34-45.

Oliver, R. (1997). Satisfaction: A behavioral perspective on the consumer. New York: McGraw-Hill.

Packer Fresh Trends. (1998). A profile of fresh produce consumers. Overland Park, KS: Vance Publishing Corp.

Parasuraman, A., Zeithaml, V., \& Berry, L.L. (1988). SERVQUAL: A multiple-item scale for measuring consumer perceptions of service quality. Journal of Retailing, 64(1), 12-40.

Putnam, J.J., \& Allshouse, J.E. (1999). Food consumption, prices and expenditures, 1970-1997. USDA/ERS Statistical Bulletin 965.

Rhodus, T., Schwartz, J., \& Hoskins, J. (1994). Ohio consumer opinions of roadside markets and farmers' markets. Ohio State University, Department of Horticulture.

Rigotti, S., \& Pitt, L. (1992). SERVQUAL as a measuring instrument for service provider gaps in business schools. Management Research News, 15, 9-17.

Sampson, S.E. (1999). Axiomatic justification for a geometric quality aggregation function. Decision Sciences Journal, 30(2), 415-440.

Schatzear, R., Tilley, D., \& Mosel, D. (1989). Consumer expenditures at direct produce markets. Southern Journal of Agricultural Economics, 21(1), 131-138.

Spreng, R.A., MacKenzie, S.B., \& Olshavsky, R.W. (1996). A reexamination of the determinants of consumer satisfaction. Journal of Marketing, 60, 15-32.

Stevens, P.B., Knutson, B., \& Patton, M. (1995). DINESSERV: A tool for measuring service quality in restaurants. Cornell Hotel and Restaurant Administration Quarterly, 36, 56-60.

Stigler, G. (1961). The economics of information. Journal of Political Economy, 69, 213-25.

Young, C., Cunningham, L., \& Lee, M. (1994). "Assessing service quality as an effective management tool: The case of the airline industry. Journal of Marketing Theory Practice, 2, 76-96.

Zeithaml, V.A., Parasuraman, A., \& Berry, L.L. (1990). Delivering quality service: Balancing customer perceptions and expectations. New York: Free Press.

David B. Eastwood is a Professor in the Department of Agricultural Economics, University of Tennessee, Knoxville. He received a BA in economics from Hanover College in 1966, an MA in economics from Brown University in 1968, and a PhD in economics from Tufts University in 1972. Current research focuses on food marketing, consumer demand, food safety, and food insecurity.

John R. Brooker is a Professor in the Department of Agricultural Economics, University of Tennessee, Knoxville. He has a BS in agricultural economics from the University of Florida, 1961, an 
MS in agricultural economics from the University of Florida in 1963, and a PhD in agricultural economics from the University of Florida in 1973. His current research interests focus on marketing and price analysis, market structure, competitive position, and market feasibility in the fruit and vegetable industry and the horticultural industry.

James D. Smith received his BS in animal science from the University of Tennessee, Knoxville in 1998 and his MS in agricultural economics from the University of Tennessee, Knoxville in 2001. He is currently working in the agribusiness sector. 